\title{
Design for life: strategic actions to boost blood donations
}

\author{
Mariana Müller Rocha ${ }^{a}$, Fabiane Vieira Romano \\ aerdi Design \\ bUniversidade Federal de Santa Maria \\ e-mail: marimullerrocha@hotmail.com; fabiromano@gmail.com
}

\begin{abstract}
This paper presents the development of design strategies to increase the number of blood donations at Regional Blood Center in Santa Maria. To accomplish it was done some theorical research, for the Design and blood donation, an interview with the residents of Santa Maria, to try to know the society, to find out why the number of donation is so low, and the main reasons for grant or no donation, and also the survey data with the Blood Center. Through analysis it is clear that an important target audience, which can be encouraged to donate blood, is composed by college students because they fit the requirements for donation and they represent a large portion of society. It was conceived through actions aimed at more permanent awareness campaigns, usually ephemeral and punctual, starting by developing a visual identity needed to recognize the theme.
\end{abstract}

Keywords: design, blood donation, branding.

\section{Introduction}

This article's goal is to present a work assignment done as a final project for the Desenho Industrial (Graphic Design) course from the Federal University of Santa Maria, RS, Brazil (ROCHA, 2013), in which thinking in social design, the author applied design knowledge to develop actions and strategies to promote awareness among university students to donate blood and increase the donations at the Santa Maria Regional Blood Bank.

In Brazil, according to the national health department, Ministério da Saúde, a little more than $1 \%$ of the population is a blood donor (BLOG DA SAÚDE, 2011). Even though this percentage is in accordance to the recommended by the World Health Organization (WHO) - 1\% to 3\% - the Brazilian health authorities consider the increase of donors an urgent matter.

The Blood Banks are frequently on the news, always pleading for donors to prevent shortage. It is an everyday drama well known by the population.

People that suffer accidents, or have to go through surgeries with the need of blood transfusions, suffering from hemophilia, leukemia, anemia and undergoing chemotherapy, among others, depend on the solidarity and good will of people that donate blood, because they need it to live. And although technology has developed incredibly on the last decades, still blood cannot be fabricated, and there is no substitute for it.

Another fact that is just as critic is that on the age of information the majority of the population doesn't now that donating blood is quick, easy, painless and risk free.
Marzari, Nascimento and Plácido (2012) state that the lack of knowledge about the importance of donating blood can be observed even among health areas students.

[...] it appears that the campaigns, most of the time, can make the problem visible and disseminate information through the media, but the effect seems limited and temporary. There is evidence that the change behavior is not permanent, that is, with the suspension of the campaigns, the behavior tends to be extinguished. (MARZARI; NASCIMENTO; PLÁCIDO, 2012, p. 01).

While campaigns are happening, the number of donations increases, but as soon as it ends, the donations decrease again.

At the Regional Blood Bank in Santa Maria, for instance, November is the month with the higher number of donations, because on November 25th it is the Nation Blood Donor day, and because of that the media exposes the subject to the general public, and campaigns are done. From December on, the donations begin to decrease rapidly, because of the holidays and school vacation. And the situation is no different in other parts of Brazil. It is a situation that makes it very important to work on building a "donation culture" among a population that is scared to donate blood or doesn't know about the process. Just as important is to keep the cause alive, as the saying goes "what is not seen, is not remembered".

And what does Design has to do with it? Design is defined by Redig (1997, p. 32) as 
[...] an equation of factors: ergonomic, perception, anthropologic, technologic, economic and environmental in the design of elements and structures necessary to life, wellbeing and culture of mankind [...].

It is problem solving!

Santos (2000 apud TEIXEIRA, 2005) considers design - profession that uses creativity to find innovative solutions - as key to the success of organizations. Also has a vision of it as a master process, because it affects different levels (strategic, tactic and operational)and areas of an organization.

The insertion of design activities in a strategic plan became a priority, materialized through a management focused on identifying, diagnosing and solving business issues. [...]
The Design has the power to integrate brand, innovation and value when inserted since the beginning of the strategic process. The design is also responsible for the success of the product and to maintain the image of the corporation in the market (TEIXEIRA, 2005, apud CASTRO and CARDOSO, 2010, p. 1.

Design can be a part of any business from the strategic planning to the creation of the brand exposure, going through the creation of experiences, processes, services and products (Figure 1). Teixeira (2005) states that the incorporation of design on the business strategy makes the organization an agent of transmission of knowledge, and offers innovative results, more adequate to its use and to the environment.

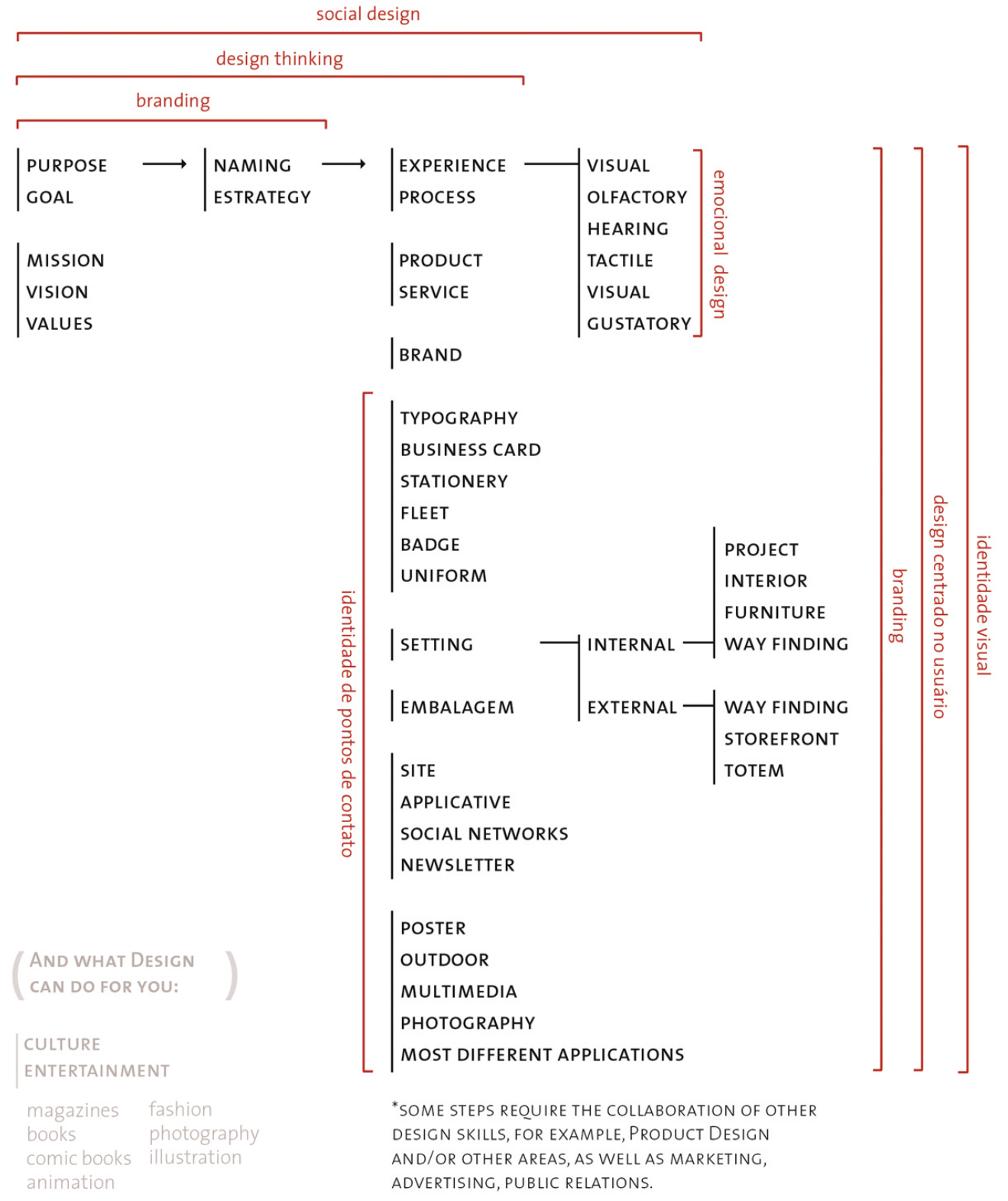

Figure 1. What design can do for your company. 
Design has the power to make the user loyal to a brand, and also to educate the society. The designer has an important role as an agent of changes in the society. He is the one that creates objects that can be considered "vehicles of interaction and social exchange", contributing to the evolution of an idea and not just commercial oriented actions (DEVIÁ, 2003 apud TEIXEIRA, 2005), for example, trying to motivate blood donations. After all, nobody is free of the need of blood transfusions, suffering an accident, or having to go through surgery or a medical procedure that blood transfusion is absolutely necessary. (VARELLA, 2012).

\section{Understanding the context}

The Regional Blood Bank in Santa Maria opened for donations on May $8^{\text {th }}, 2008$, and it is the responsibility of a partnership between the Health Production and Research State Foundation - FEPPS, the University of Santa Maria, through its teaching hospital, and the Santa Maria City Hall (SANTA MARIA, 2012a). The purpose of its creation was to improve the blood donations service, which before was done by the Santa Maria University teaching hospital - HUSM, and the place brought hope to increase the number of donors. With state of the art equipment, it was designed to receive about 1,200 donors per month. After many campaigns, the blood bank still works bellow its capacity, because of the lack of blood donors (INFO CAMPUS, 2011). The goal was to provide blood for all the central region of the state, but because of the low numbers of donations, it is hard to even maintain the stock of the city hospitals. Many times they ask for the army help to have temporary donations units on nearby cities.

As for the city, Santa Maria, according to IBGE (INSTITUTO..., 2011), has approximately 262.000 habitants. And thanks to the Santa Maria University, it is considered a college city. The city has many other education institutions, and an estimate of $\mathbf{3 5}$ thousand college students (AGÊNCIA..., 2012).

According to the World Health Organization, if 3\% to $4 \%$ of the population donated blood, there would be no shortage of stock (HEMOCENTRO..., 2012).

Considering this important social demand and the number of colleges in the city with its high number of potential donors (Figure 2), the goal was to attract student's attention, people that have the characteristics necessary for donation, for this important cause, which would be otherwise only remembered when a family member or a friend is in need of a blood donation.

We all know that it is important to donate blood. But when it's our turn, we always find an excuse - today is cold or I am not willing; these last days I have been working hard and I'm tired, what if I need this blood... - and we postpone the donation that could save a person's life (VARELLA, 2012, p.01).
Figure 2 shows the relation between the number of college students, the population of Santa Maria, and the number of donations according to WHO recommendation. It can be observed the excellent opportunity to contribute with design knowledge to this noble cause.

\section{IN SANTA MARIA}

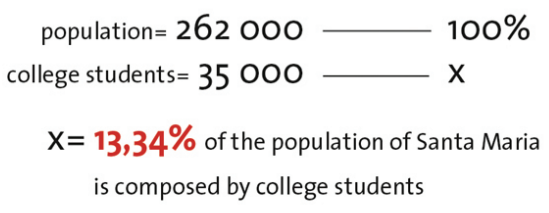

$3 \%$ TO $4 \%$ WOULD NOT FAIL STOCK
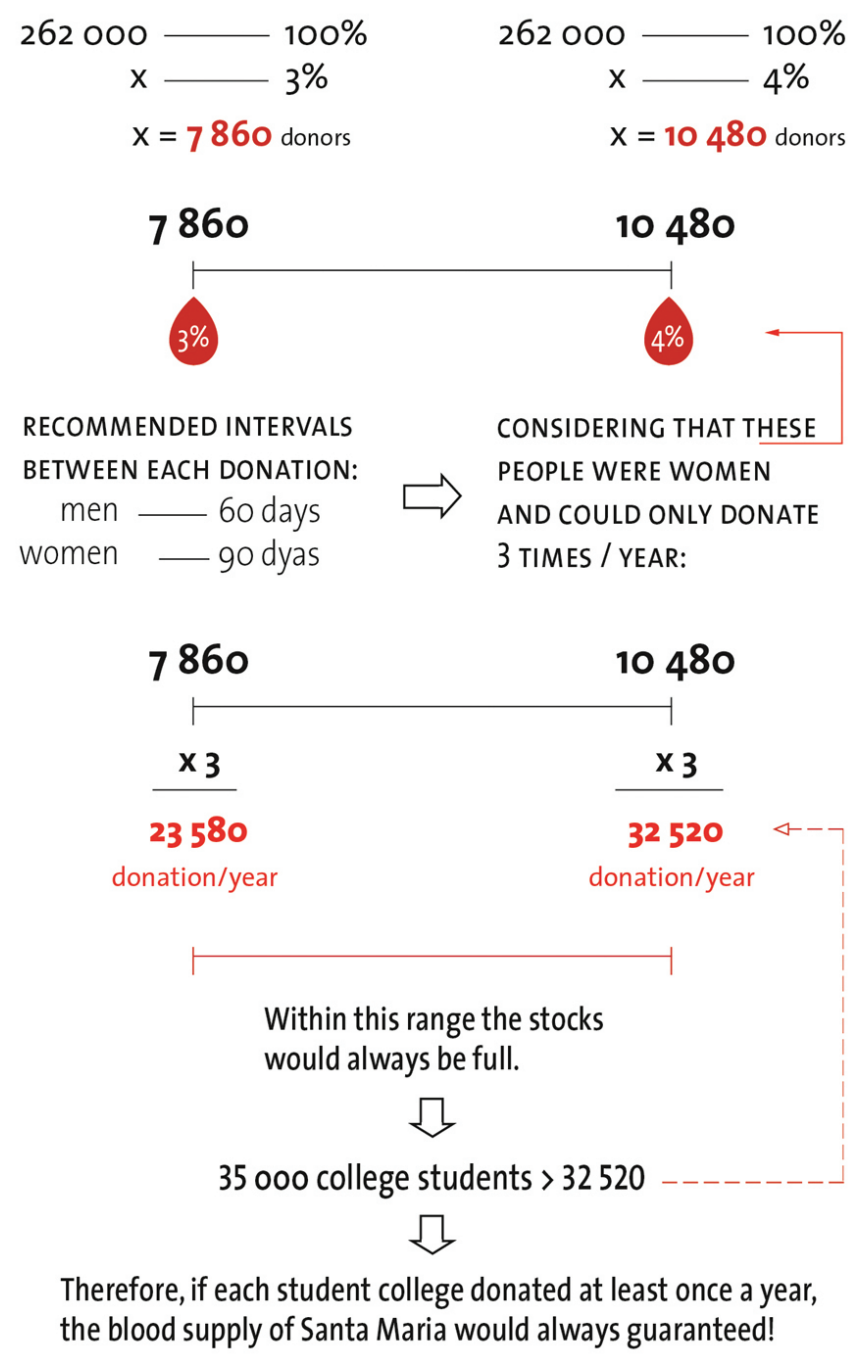

Figure 2. Relation between college students and blood donations in Santa Maria. Source:Agência Desenvolvimento de Santa Maria, 2012; IBGE, 2011; Hemocentro Regional de Santa Maria, 2012. 


\section{The project}

The starting point of the study was a research done with the blood bank, where the location, building, routine and blood donation processes were analyzed.

The first thing was the donation process. Donating blood is simple, confidential, safe and almost painless, and the donor has to go through the following steps (HEMOSC, 2012): (i) Reception and registration: presenting identification documents to register or check personal data; (ii) Triage: checking weight, height, blood pressure, pulse and temperature and the anemia test - a small drop of blood is collected to make sure the candidate is not suffering from anemia; (iii) Clinical Interview: absolutely confidential (at this point it is very important to trust the interviewer and be honest), the donor signs Term of Consent, where he states that he understands the information given, that he was honest in his interview, that he agrees freely with the donation, and that he is aware that if any blood tests are not normal, he will be called by the donor support service; (iv) Donation: the collection of blood is done, $450 \mathrm{~mL}$ and samples for the mandatory tests; After the collection, the blood bags are sent to centrifugation. At this point the blood is separated in four parts: red blood cells, platelets, plasma and cryo; (v) Snack: the donor receives a snack with liquids, to replace the blood taken, and is informed about the importance of drinking lots of liquids. The collection takes about 5 to 7 minutes, and the whole process about 30 minutes (INFO CAMPUS, 2011). The amount of blood takes is less than $10 \%$ of the total body volume, and it is quickly replaced.

Then why people don't donate?

Observing the blood bank, what came to attention was that, in spite of being new and well equipped, with a good team of specialists and all the efforts to attract more donors, it is difficult to find the blood bank. The building is not identified, and there are no signs or indication of the donating place. Also, the access for pedestrians is difficult - only one bus line pass by in random hours and from very few neighborhoods - making it very difficult for donors to get there. (SANTA MARIA, 2012b).

As for the target public, to better understand its motivations, reasons not to donate and knowledge about the blood bank, a questionnaire was done, trough Google Docs, and 209 valid answers were obtained. Approximately $70 \%$ of the interviewees - with an average age of 24.5 year old and being $65 \%$ college students - had never donated blood, when only $30 \%$ had. Besides that, among the ones that had donated before, only $6.77 \%$ are frequent donors (donating every 3 months for women, and every 4 months for men); $45 \%$ donated only one time; $14 \%$ from 2 to 4 times and $41 \%$ rarely. Among the $30 \%$ that has donated blood before, the main reason for doing so was charity, with $74.5 \%$, and the second reason was for having family of acquaintance in need of blood (58\%), proving that if blood donation is promoted as a charity cause, there will be an increase in awareness for it.

To increase the number of blood donors, mainly through awareness for the cause among college students, the first step was to create a visual identity for the brand "Doe Sangue" - donate blood, as part of an strategy to familiarize the public with the idea, and to create efficient contact points. Also it would be very interesting to work on partnership projects, such as: (i)with schools, to guarantee the future donations, creating an awareness of the value of donating; (ii) with companies, to create a culture of donation, encouraging employees to donate, showing the importance of the act and the importance to become a frequent donor, not overloading the few frequent donors; and (iii) with universities, to encourage the "awareness hoax", taking new students to the blood bank on registration day.

The creation of the brand started with image research, and then the basic necessary requisitions were defined: simplicity, easy understanding, contemporaneity and tri dimensionality. Many drafts were made to reach an ideal form that, after digitalized, went through tests of color, typography and diagramming. Figure 3 is the result of the final brand, and its descriptive memorial.

For the immediate application of the brand, the points of contact defined were: t-shirts - so the idea could be worn, mugs and bags for stores.

Besides that, as the main answer to those who haven't donated blood claiming they don't have time, and considering that in spite of the process taking about 30 minutes, the donation takes only 7 , and that with the blood donated it is possible to make 4 transfusions; these numbers were used to show that donating blood is quick and it is a very important contribution. And with this visual appeal many applications were developed with the brand "Doe Sangue", featuring: a sign - to be put on places with high circulation of people to promote awareness; 2 outdoors - one to be out in front of bus stops and another to be put on a roundabout close to the blood bank; adhesive piece for back of buses- a point of contact that will be around, and it is used by students.

The other strategy to encourage voluntary donations is to clarify the donation process. Using the researches as a base, an informative text presented in folders and stickers, size $200 \mathrm{~mm} \times 256 \mathrm{~mm}$, that can be adhered in public bathrooms and college bathroom mirrors, in medical practices and any other businesses that want to contribute, such as restaurants, schools and beauty salons. Also a sticker that can be adhered to napkin holders in snack bars and bars - places with high young people attendance. Figure 4 shows some of these applications. 


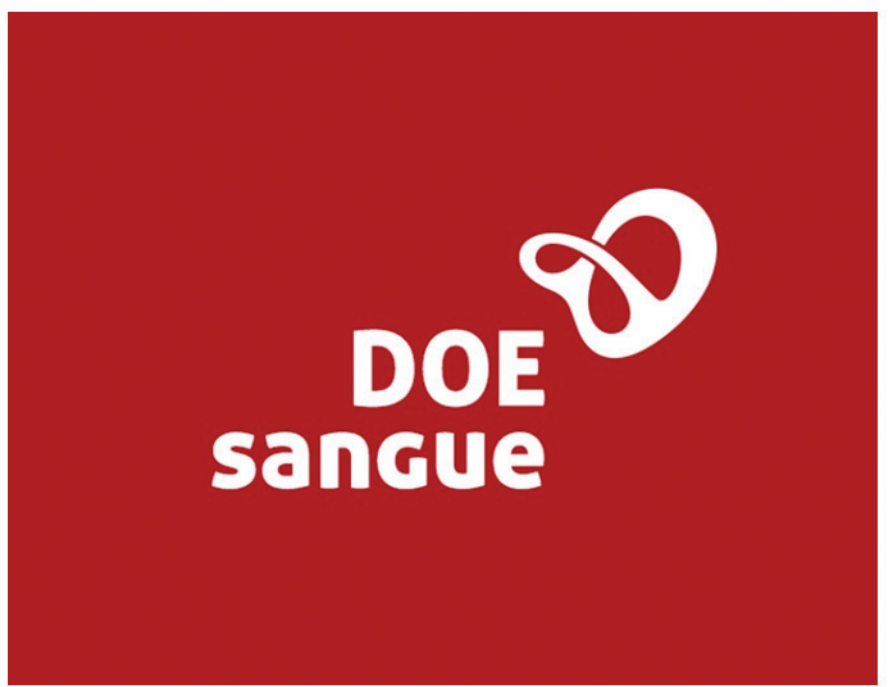

The visual identity "Donate Blood" is composed of symbol and logo.

The symbol is a representation of a $3 \mathrm{D}$ heart, formed only by a line, bringing the idea of union, that together we can more. The angle presented, the way we see, is a drop in the hollow, making reference to blood.

For the logo we sought a free font that meets the necessary requirements. The choice was a sans serif Aller, of Dalton Maag. Humanist, good readability, its curves and its weight combined with the symbol.

For the color red was used because it is the first color perceived by the human eye, an alert color and to be a part of our cultural repertoire referring to the blood.

Figure 3. The brand "Doe Sangue" e its descriptive memorial.
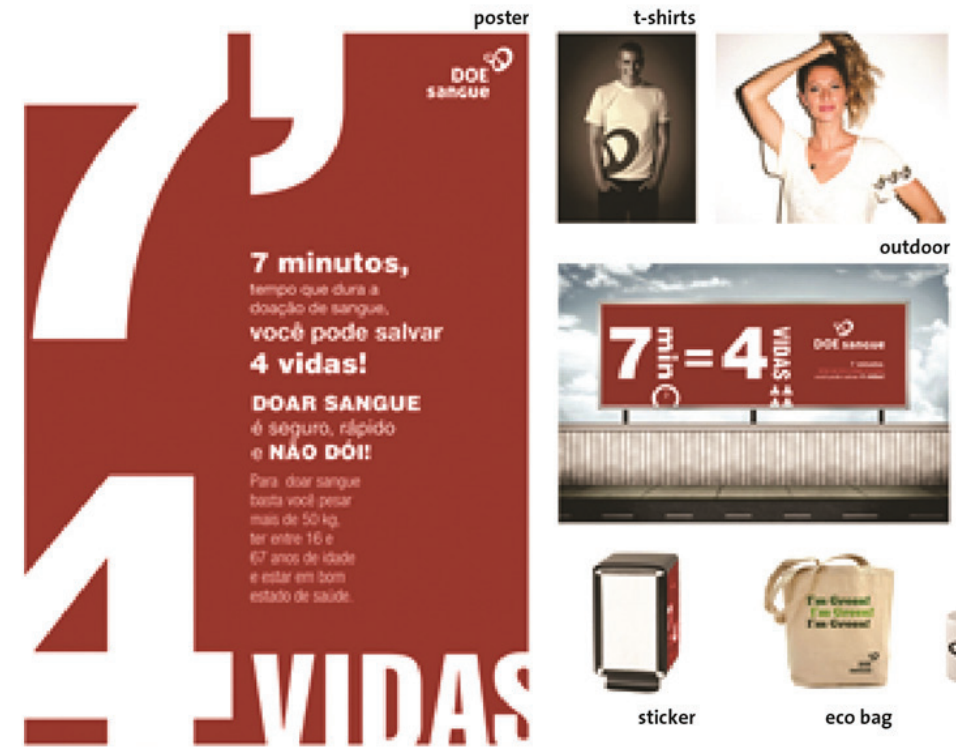

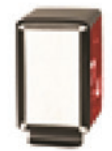

sticker

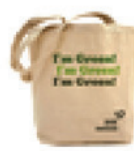

eco bag
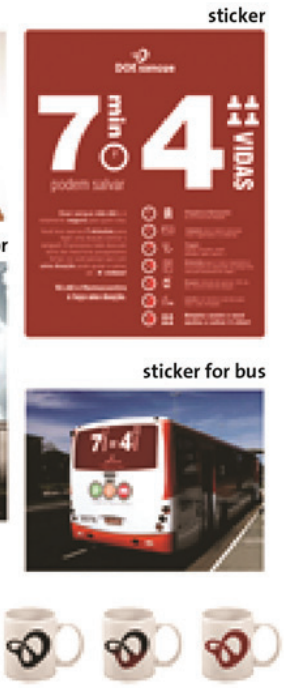

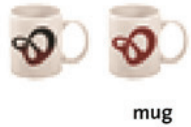

informative folder

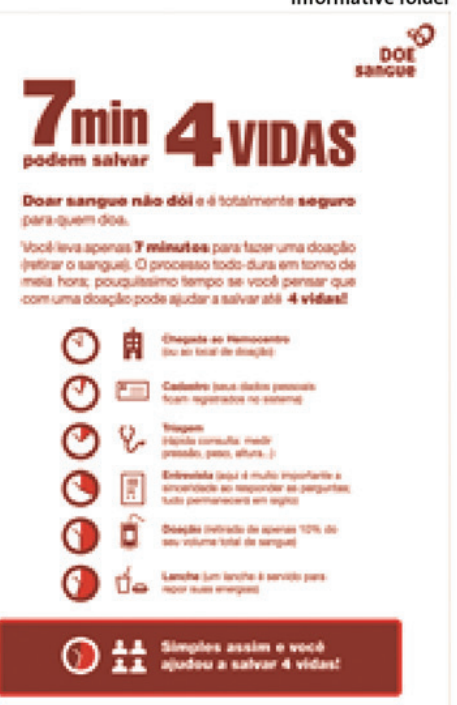

Figure 4. Some applications made for the project.

Today's companies of every segment use social networks to get closer to target audiences; therefore a Facebook page was developed to connect college students to the blood bank. As a profile picture, the brand was used, and the cover photo is a map, showing how to get to the blood bank. And to help with the signalization, a sign was developed for the building access area (Figure 5).

\section{Final considerations}

When discussing product development, one has to consider that:

There will always be a market for products and services that are desired or needed, that make the world a better place, and make life easier. Some of these desires and needs are influenced by marketing actions, others are part of trends and broader social concerns, such as a higher awareness for health issues [...] (BEST, 2012, p.42).

It is precisely in this context that this project was done, hoping to help an important cause, show how design can play a fundamental role in improving quality of life, and how a designer can solve problems that are connected to a social need.

The hope is that this project, if implemented, can in fact be a contribution for the Regional Blod Bank, increasing blood donations in Santa Maria, and maybe even serving as inspiration for other designers working on social projects. 

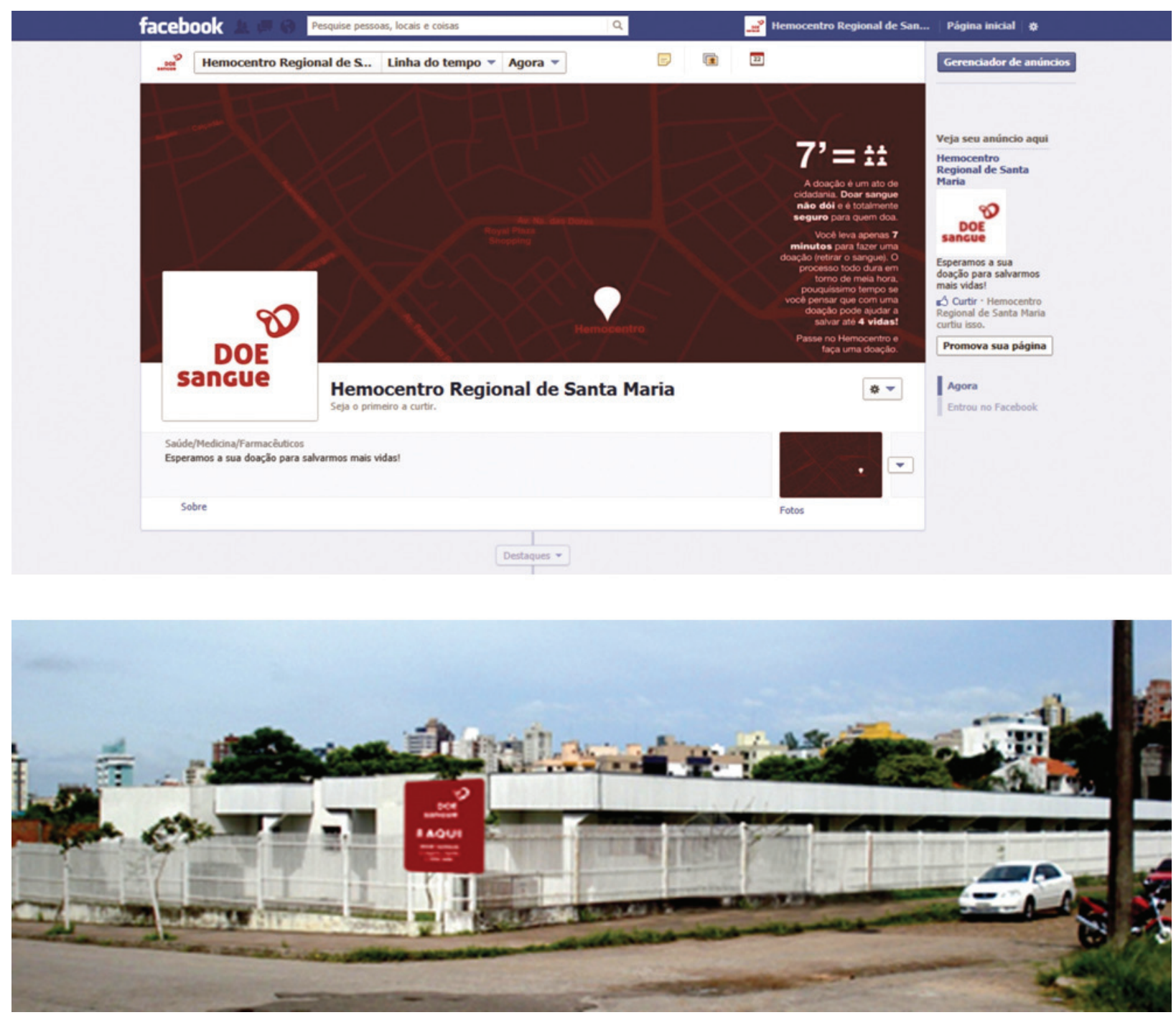

Figure 5. Digital disclosure and local signage.

\section{References}

AGÊNCIA DE DESENVOLVIMENTO DE SANTA MARIA - ADESM. Número de estudantes universitários em Santa Maria. Disponível em: <http://adesm.org.br/ santa-maria>. Acesso em: 25 nov. 2012.

BEST, K. Fundamentos de Gestão do Design. Porto Alegre: Bookman, 2012.

BLOG DA SAÚDE. Dia Nacional do Doador Voluntário de Sangue. 2011. Disponível em: <http://http://www.blog. saude.gov.br/hoje-e-o-dia-nacional-do-doador-voluntariode-sangue/>. Acesso em: 24 abr. 2012.

CASTRO, M. L. A. C. de; CARDOSO, J. Design estratégico: taxonomias e inserção em contextos contemporâneos. Available from: <http://http://blogs.anhembi.br/ congressodesign/ anais/artigos/68640.pdf $>$. Access in: 05 Jun. 2012.
HEMOCENTRO REGIONAL DE SANTA MARIA. Levantamento de Dados. Santa Maria, 2012.

HEMOCENTRO REGIONAL DE SANTA CATARINA. Doação de Sangue. Disponível em: http://www.hemosc. org.br/doacao-de-sangue >. Acesso em: 24 abr. 2012.

INFO CAMPUS. Fidelizar doadores é um desafio no Hemocentro Regional de Santa Maria. 2011. Disponível em: <http://w3.ufsm.br/infocampus/?p=4521>. Acesso em: 22 jan. 2012.

INSTITUTO BRASILEIRO DE GEOGRAFIA E ESTATÍSTICA - IBGE. Santa Maria, RS. 2011. Disponível em: <http://www.ibge.gov.br/cidadesat/painel/painel. php?codmun $=431690 \#>$. Acesso em: 25 nov. 2012.

MARZARI, C. K.; NASCIMENTO,A.; PLÁCIDO, S. Captação de Doadores de Sangue. Disponível em: <http://http://www. clicrbs.com.br/dsm/rs/ impressa/4,41,3724359,19381>. Acesso em: 16 abr. 2012. 
REDIG, J. Sobre Desenho Industrial. Rio de Janeiro: ESDI, 1977.

ROCHA, M. M. Design para a vida: Ações estratégicas para aumentar as doações de sangue. 2013. Trabalho de Conclusão de Curso (Graduação em Desenho Industrial)Universidade Federal de Santa Maria, Santa Maria, 2013.

SANTA MARIA. Solidariedade: participe das ações da Semana Nacional da Doação de Sangue que vai até o dia 24 de novembro. 2012a. Disponível em: <http://www. santamaria.rs.gov.br/saude/noticias/5743-solidariedadeparticipe-das-acoes-da-semana-nacional-da-doacao-desangue-que-vai-ate-o-dia-24-de-novembro $>$. Acesso em: 22 jan. 2012.
SANTA MARIA. Verdades sobre o Hemocentro. 2012b. Disponível em: <http://www.clicrbs.com.br/dsm/rs/ impressa/4,41,3325510,17205>. Acesso em: 22 jan. 2012.

TEIXEIRA, J. A. O Design Estratégico na Melhoria da Competitividade das Empresas. 2005. Tese (Doutorado em Engenharia de Produção)-Universidade Federal de Santa Catarina, Florianópolis, 2005. Disponível em: <http:// www.tede.ufsc.br/teses/PEPS4703.pdf>. Acesso em: 05 jun. 2012.

VARElla, D. Dia Mundial do Doador de Sangue. Disponível em: <http://drauziovarella.com.br/wiki-saude/ doacao-de-sangue/>. Acesso em: 23 jan. 2012. 